\title{
ARTIGOS 0 Conselho Nacional de Justiça e a Academia
}

\author{
Por Fabiana Luci de Oliveira \\ Pâmela Tieme Barbosa Aoyama
}

\begin{abstract}
Resumo: $\mathbf{O}$ artigo mapeia a produção de conhecimento acadêmico acerca da atuação do Conselho Nacional de Justiça (CNJ), documentando como tem se dado o diálogo entre CNJ e academia. 0 levantamento feito a partir de registros no Banco de Teses e Dissertações da CAPES apontou um total de 248 trabalhos indexados pelo termo "CNJ". Após avaliação da pertinência temática e da disponibilidade do texto completo, 115 trabalhos foram analisados e codificados em onze aspectos. Observou-se que as pesquisas têm privilegiado o estudo da atuação do CNJ no âmbito da gestão do Poder Judiciário, com ênfase nas ações de planejamento estratégico voltadas para o combate à morosidade. 0 tema menos estudado, a competência disciplinar do Conselho, permitiu concluir que o desempenho do poder disciplinar do CNJ ainda é restrito, sendo sua contribuição principalmente no âmbito de uniformização administrativa, mais do que no âmbito punitivo, até mesmo devido às limitações normativas de cunho sancionador.
\end{abstract}

PALAVRAS-CHAVE: Conselho Nacional de Justiça, Pesquisa, Pós-graduação, Brasil.

Abstract: The article maps the academic knowledge production about the National Council of Justice (CNJ) performance, documenting how the dialogue between CNJ and academia has taken place. The search conducted in CAPES's thesis and dissertations portal pointed out 248 works indexed by the term "CNJ". After evaluating the thematic appropriateness and the full text availability, 115 papers were analysed and codified in eleven factors. It was observed that research has privileged the study of CNJ's performance in the Judiciary Power management framework, with emphasis on the strategic planning actions aimed toward tackling procedural tardiness. The less studied theme was the Council's disciplinary competence. Due to the normative limitations of the sanctioning nature, it lead to two conclusions: (1) CNJ's disciplinary power is still restricted, and (2) its contribution is more in the area of administrative uniformity, rather than punitive actions.

KEYWORDS: National Council of Justice, Research, Graduate Programs, Brazil

\section{Introdução}

O Conselho Nacional de Justiça (CNJ) completa em junho de 2017 doze anos de atividade, tendo como marco inaugural a primeira sessão realizada em 14 de junho de 2005 . Instituído pela EC n. 45/2004 como órgão de governança do Poder Judiciário nacional, sua atuação está voltada ao planejamento e gerenciamento de ações de aperfeiçoamento do sistema judiciário brasileiro e à promoção da qualidade da prestação jurisdicional, garantindo, sobretudo, o controle e a transparência administrativa e processual, buscando corrigir eventuais deficiências, almejando uma maior eficiência do sistema judiciário.

Entre suas atribuições, previstas no art. $103-\mathrm{B}, \S 4^{\circ}$, da Constituição Federal, estão a definição do planejamento estratégico, dos planos de metas e dos programas de avaliação institucional do Poder Judiciário; a produção e a divulgação de indicadores sobre movimentação processual e performance da atividade jurisdicional em todo o País; e o julgamento de processos disciplinares contra magistrados. Dessa forma, pode ser considerado não apenas um órgão de governança, como também de accountability. Nesses 12 anos foram seis composições ${ }^{1}, 247$ sessões plenárias $2,68.449$ processos distribuídos e 63.281 finalizados (arquivados)3, 244 Resoluções e 68 Recomendações publicadas ${ }^{4}$.

Decisões de grande repercussão do Conselho incluem a proibição da prática do nepotismo no Poder Judiciário, com a publicação da Resolução CNJ n. 7, de 18/10/2005, que, como disposto na ementa, disciplinou o exercício de cargos, empregos e funções por parentes, cônjuges e companheiros de magistrados e servidores investidos em cargos de direção e assessoramento, no âmbito dos órgãos do Poder Judiciário ${ }^{5}$; e a garantia do direito dos casais homoafetivos celebrarem casamento civil, com a publicação da Resolução CNJ n. 175, de 14/05/2013, que, conforme a ementa, dispõe sobre a habilitação, celebração de casamento civil, ou de conversão de união estável em casamento, entre pessoas de mesmo sexo ${ }^{6}$.

Outro aspecto relevante da atuação do Conselho está nas penas disciplinares aplicadas a magistrados, sendo que desde sua instalação em junho de 2005 até março de 2017, o CNJ decidiu pela aposentadoria compulsória de 51 magistrados, estando entre os fundamentos dessas decisões o recebimento de vantagens indevidas em troca de sentenças judiciais, negligência na condução de processos e outras violações ao Código de Ética da Magistratura?.

1. De acordo com o art. 103-B da Constituição Federal, o CNJ é composto por quinze membros, com mandato de dois anos, permitida uma recondução, sendo: De acordo com o art. 103-B da Constituição Federal, o CNJ é composto por quinze membros, com mandato de dois anos, permitida uma recondução, sendo: 0 Presidente do Supremo Tribunal Federal, um Ministro do Superior Tribunal de Justiça, que sera o Corregedor Nacional de Justiça; um Ministro do Tribunal Superio do Trabalho; um Desembargador de Tribunal de Justiça; um Juiz Estadual; um Juiz do Tribunal Regional Federal; um Juiz Federal; um Juiz de Tribunal Regional do Trabalho; um Juiz do trabalho; um Membro do Ministério Público da União; um Membro do Ministério Público Estadual; dois advogados e dois cidadãos de notável saber jurídico e reputação ilibada.

Até março de 2017.

Informações até março de 2017 de acordo com o painel do PJe.

http://www.cnj.jus.br/atos-normativos.

http://www.cnj.jus.br/busca-atos-adm?documento $=2716$

http://www.cnj.jus.br/busca-atos-adm?documento=2504

Informações da Corregedoria Nacional de Justiça. http://www.cnj.jus.br/corregedoriacnj/de-gestao. 
Suas atribuições, sobretudo de fiscalização e investigação, não foram aceitas sem resistência, mormente dos interesses corporativos, sendo que a Associação dos Magistrados Brasileiros (AMB) contestou a criação de um órgão independente para fiscalizar e propor políticas públicas para o Poder Judiciário, via ADI n 3.367-1, que foi julgada improcedente pelo STF, em 13/05/2005 ${ }^{8}$.

Passados doze anos dessa decisão e da instalação do CNJ, o objetivo desse artigo é documentar o que tem sido produzido de conhecimento acadêmico (técnicocientífico) acerca da atuação do Conselho Nacional de Justiça, mapeando como tem se dado o diálogo entre CNJ e academia, com o $\mathrm{CNJ}$ sendo objeto de estudo em pesquisas voltadas a analisar sua criação, instalação, e a eficácia e efetividade com que tem desempenhado suas funções.

\section{O CNJ como objeto de pesquisa}

Nossa proposta aqui é documentar a produção de conhecimento técnico-acadêmico existente acerca do CNJ, mapeando pesquisas publicadas sobre o Conselho a partir do levantamento da produção da pós-graduação (teses e dissertações).

\section{Levantamento de teses e dissertações}

O objetivo do levantamento foi identificar as teses e dissertações em que o Conselho Nacional de Justiça (CNJ) foi objeto de estudo. A plataforma de busca utilizada para essa pesquisa foi o Banco de Teses e Dissertações da CAPES $^{9}$.

A estratégia de mapeamento dos trabalhos considerou o termo de busca "Conselho Nacional de Justiça", entre aspas, e não restringiu área do conhecimento, data ou instituição, de forma a obter um levantamento exaustivo.

No levantamento inicial, com busca realizada em janeiro de 2017, foram recuperadas 209 teses e dissertações indexadas pelo termo. Em fevereiro do mesmo ano foram incluídos mais 40 trabalhos na base de dados, sendo que um trabalho estava duplicado na listagem. Ao final do levantamento, 248 teses e dissertações foram recuperadas.

Avaliamos a pertinência das teses e dissertações para compor nosso mapeamento a partir da menção ao CNJ no título, no resumo ou nas palavras-chave. E aplicamos um segundo filtro: a disponibilidade ou não do texto completo. Para aqueles trabalhos não localizados integralmente na base de dados da CAPES, contatamos os referidos Programas de Pós-graduação e os próprios autores (a partir da plataforma lattes), solicitando o acesso ao texto completo. Consideramos as respostas enviadas até o dia 31/03/2017 e fechamos nossa seleção com um total de 115 trabalhos.
Para esses 115 trabalhos, codificamos onze aspectos:

1. Título: título da tese ou dissertação defendida;

2. Autor (a): autor (a) da tese ou dissertação defendida:

3. Orientador (a): professor (a) que orientou tese ou dissertação defendida;

4. Ano de defesa: ano em que a tese ou dissertação foi defendida;

5. Instituição: universidade ou faculdade em que a tese ou dissertação foi defendida;

6. Área de conhecimento: área do conhecimento do programa de pós-graduação em que tese ou dissertação foi defendida;

7. Nível de titulação: nível educacional da pósgraduação, se mestrado (dissertação) ou doutorado (tese);

8. Objeto de estudo: especificando se o CNJ é objeto central ou secundário do estudo;

9. Tema: especifica o aspecto da atuação do CNJ que é foco da pesquisa, se sua atribuição de gestão ou disciplinar ou ainda aspectos institucionais;

10. Assunto: especifica a problemática levantada pela pesquisa - o que exatamente está sendo estudado;

11. Metodologia: especifica qual a forma de condução da pesquisa, se o trabalho tem base empírica ou não, e caso tenha se a abordagem é quantitativa, qualitativa ou mista;

Fazemos a ressalva de que nosso levantamento não é exaustivo, ou seja, não cobrimos toda a produção acadêmica acerca do $\mathrm{CNJ}$, uma vez que não incluímos aqui livros ou capítulos de livros, papers apresentados em congressos ou artigos publicados em periódicos ${ }^{10}$. Mas voltamo-nos à análise de parte relevante da produção acadêmica, que é a produção dos programas de pós-graduação, o que nos permitiu identificar as principais tendências dos estudos acerca do Conselho Nacional de Justiça. São essas tendências que discutimos ao longo do artigo.

\section{Uma década de pesquisas sobre o CNJ (2006-2016)}

Apresentamos no gráfico 1 a distribuição das teses e dissertações de acordo com o ano em que foram defendidas, e vemos que logo em 2006, menos de dois anos após a criação do $\mathrm{CNJ}$, apareceram os primeiros trabalhos sobre o Conselho. Ambos discutem aspectos do processo da Reforma do Judiciário (EC 45/2004) e a questão da legitimidade do Conselho, tematizando o temor do controle externo. Notamos que há uma tendência de crescimento da produção acadêmica acerca do CNJ ao longo do tempo, havendo um incremento significativo nessa produção a partir de 2014, quando o CNJ já completava quase uma década desde sua criação.

8. Há uma série de estudos e publicações que se dedicaram a analisar a criação e instalação do CNJ, entre os quais estão RENAULT, S. R. T. e BOTTINNI, P. Reforma do Judiciário. São Paulo: Saraiva, 2005. SADEK, M. T CNJ: O futuro na agenda In Gilmar Ferreira Mendes: Fabiano Martins Silveira; Marco Aurélio Marrafon. (Org.). Conselho Conselho Nacional de Justiça - fundamentos, processo e gestão. São Paulo: Saraiva, 2016, p. 109-124; SADEK, M. T. CNJ: impactos no Judiciário e na sociedade. In:
Stoco, Rui; Penalva, Janaína. (Org.). Dez Anos de Reforma do Judiciário e o nascimento do Conselho Nacional de Justiça. São Paulo: Editora Revista dos Tribunais, Stoco, Rui; Penalva, Jana

9. http://bancodeteses.capes.gov.br/banco-teses/\#!/.

10. Em buscas realizadas na coleção de periódicos do Scielo (http://www.scielo.br) e no portal de periódicos da CAPES (http://www.periodicos.capes.gov.br/), utilizando os termos "Conselho Nacional de Justiça" e "CNJ", recuperamos apenas 14 publicações - excluindo a sobreposição de artigos e aqueles não pertinentes ao tema. A primeira publicação data de 2012, nove artigos foram publicados em 2013, três em 2014 e um em 2016. É preciso considerar que, diversamente da produção acadêmica em teses e dissertações, disponibilizadas, em geral, com pouca distância temporal após a defesa, a publicação em periódicos costuma ser produção acadêmica em teses e dissertaçóes, disponiblizadas, em geral, com pouca distância temporal após a defesa, a publicação em periodicos costuma ser mais demorada. Os temas que apareceram nessas publicaçoes foram gestão e aspectos institucionais, responsáveis por metade dos artigos cada. Em termos de assuntos, 4 artigos trataram da legitimidade democrática do desenho do CNJ, 2 artigos da política judiciaria na area de informatização, outros 2 na área de infância e juventude, e 2 acerca da imagem pública do Conselho. Além desses assuntos, apareceram em um artigo cada a discussão da política judiciária de planejamento
estratégico, conflitos fundiários, o perfil dos conselheiros e o tema da mediação e conciliação. 


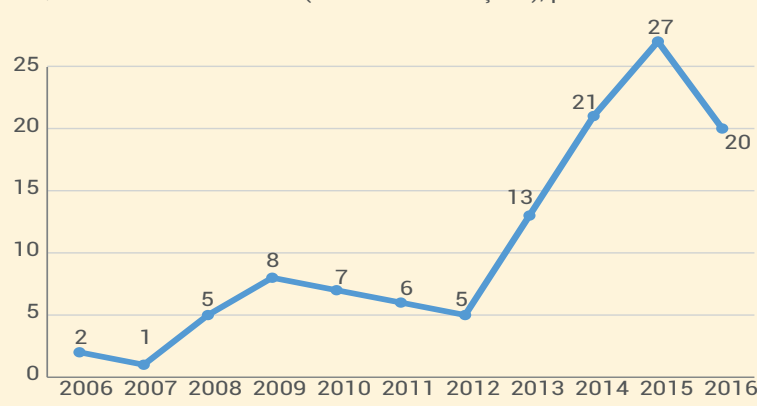

Fonte: DPJ/CNJ. Base: 115 trabalhos (teses e dissertações)

No gráfico 2, apresentamos as instituições de origem desses trabalhos, notando que há uma grande dispersão entre as instituições, sendo a Universidade Federal de Pernambuco (UFPE) a instituição que apresenta a maior quantidade de trabalhos (5\%), seguida por FGV-Rio, PUCSP, UNB, UNIFOR e USP ( $4 \%$ cada). Em outras instituições $(25 \%)$, foram classificadas todas aquelas para as quais apenas um trabalho foi localizado.

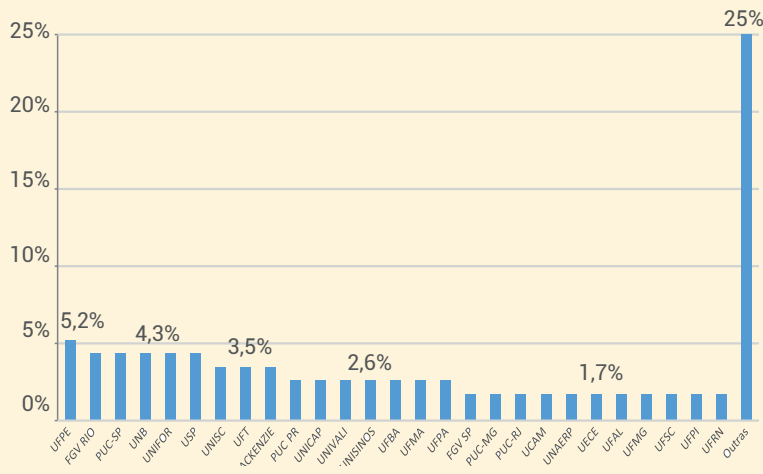

Fonte: DPJ/CNJ. Base: 115 trabalhos (teses e dissertações)

Apesar de não haver concentração no que se refere às instituições, há uma forte marca regional, com as instituições do Sudeste sendo responsáveis por $40 \%$ dos trabalhos, e o Nordeste por $28 \%$, seguido das instituições do Sul, com $20 \%$. De maneira geral, os dados refletem a própria distribuição regional da pós-graduação brasileira.

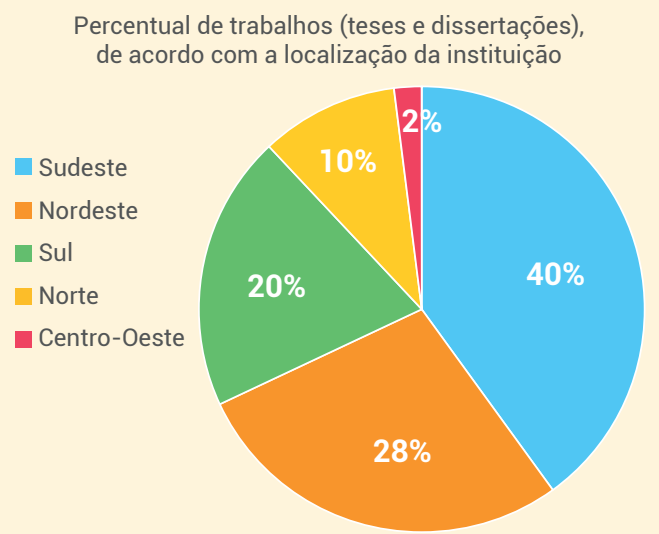

Fonte: DPJ/CNJ. Base: 115 trabalhos (teses e dissertações)

Em termos da unidade da federação em que se localizam essas instituições, temos o Estado de São Paulo como o principal polo de produção de trabalhos sobre o $\mathrm{CNJ}$, até porque é o Estado em que há maior quantidade de faculdades de Direito e de programas de pós-graduação em Direito no país.

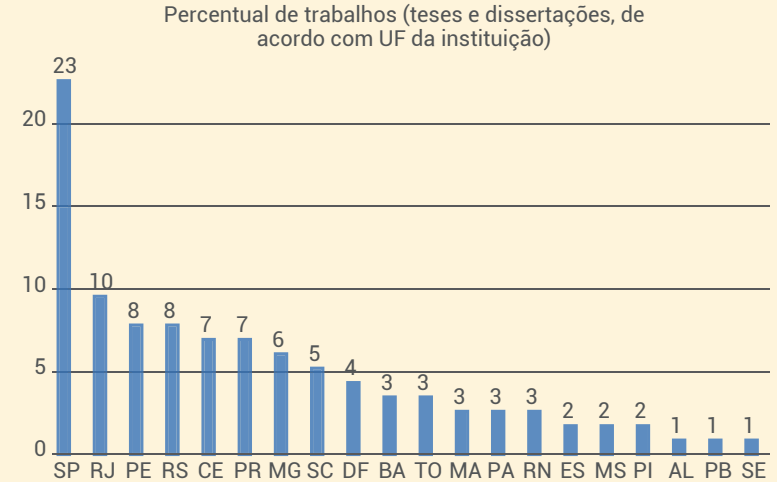

Fonte: DPJ/CNJ. Base: 115 trabalhos (teses e dissertações)

No gráfico 5 resumimos as informações sobre a área de conhecimento em que o trabalho foi desenvolvido. Notamos uma grande concentração no Direito, com os programas de pós-graduação nessa área sendo responsáveis por $60 \%$ dos trabalhos. Administração, Ciência Política e Sociologia vêm na sequência, responsáveis por $8 \%, 6 \%$ e $4 \%$ dos trabalhos, respectivamente.

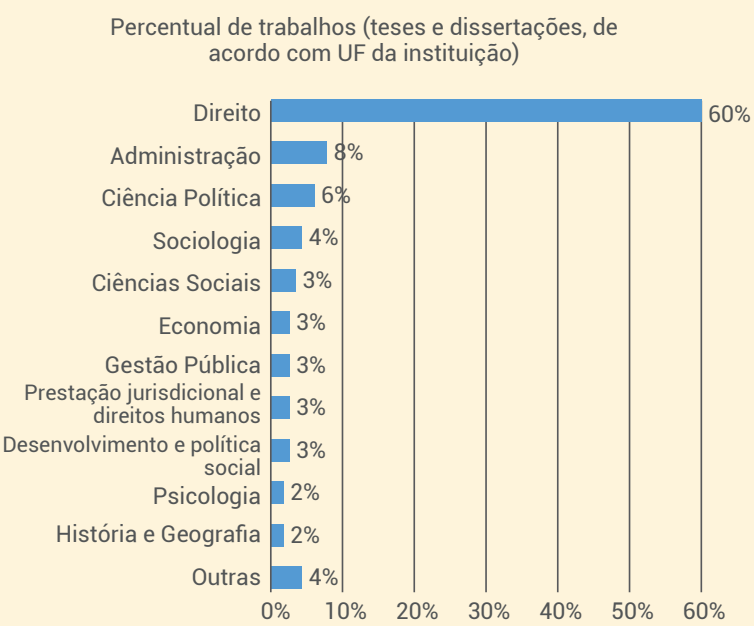

Fonte: DPJ/CNJ. Base: 115 trabalhos (teses e dissertações)

Já no gráfico 6, apresentamos o nível de titulação, sendo a grande maioria mestrados (85\%). As informações sobre título dos trabalhos e autoria estão elencadas ao final do artigo, já separadas conforme o tema central que abordam.

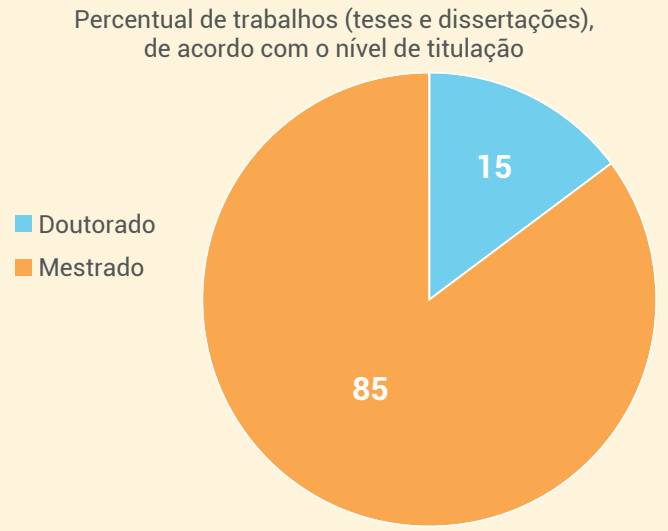

Fonte: DPJ/CNJ. Base: 115 trabalhos (teses e dissertações)

Buscamos identificar também a agência de fomento de cada uma dessas pesquisas, mas essa informação nem sempre é apresentada. Em apenas 31 dos 115 trabalhos encontramos menção à agência de fomento. Foram 
15 trabalhos financiados pela CAPES, 10 pelo $\mathrm{CNJ}^{11}$, 4 por tribunais e 2 pelo CNPq. Para as demais teses e dissertações não conseguimos observar a informação, sendo que a ausência de informação não nos permite afirmar que não tenha havido fomento.

Uma vez analisadas as informações sobre essas produções em termos de localização, instituições e áreas de saber, foi considerado o conteúdo desses trabalhos.

\section{Temas e assuntos privilegiados no estudo do CNJ}

O primeiro aspecto de conteúdo analisado foi a centralidade do CNJ na pesquisa, ou seja, trata-se de uma pesquisa sobre o Conselho em si (CNJ é o objeto de estudo central) ou trata-se de pesquisa sobre outro objeto, sendo o $\mathrm{CNJ}$ objeto secundário na análise - por exemplo, casos em que se estuda a implementação de políticas de gestão instituídas pelo $\mathrm{CNJ}$ em diferentes tribunais do país, ou mesmo estudos dos impactos de resoluções do $\mathrm{CNJ}$ em temáticas específicas, como a política nacional de conciliação, a política de adoção, entre outras temáticas. Vemos, a partir dos dados dispostos no gráfico 7 , que o CNJ é ator central em $44 \%$ das pesquisas.

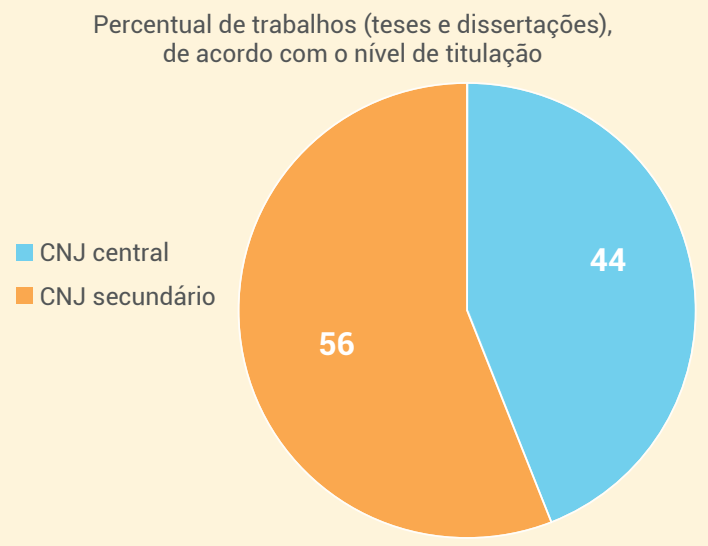

Fonte: DPJ/CNJ. Base: 115 trabalhos (teses e dissertações)

Outro aspecto de interesse foi a metodologia adotada nas pesquisas. Observamos que praticamente metade dos estudos foi conduzida a partir do emprego de desenhos empíricos (57 dos 115 trabalhos) e metade não empíricos (58 dos 115 trabalhos)

Quanto a abordagem dos estudos empíricos, houve um equilíbrio entre o uso de técnicas quantitativas e qualitativas ( $44 \%$ de pesquisas com cada abordagem), sendo que $12 \%$ dos estudos adotaram abordagem mista (combinando o uso de técnicas de geração e análise de dados quantitativas e qualitativas).

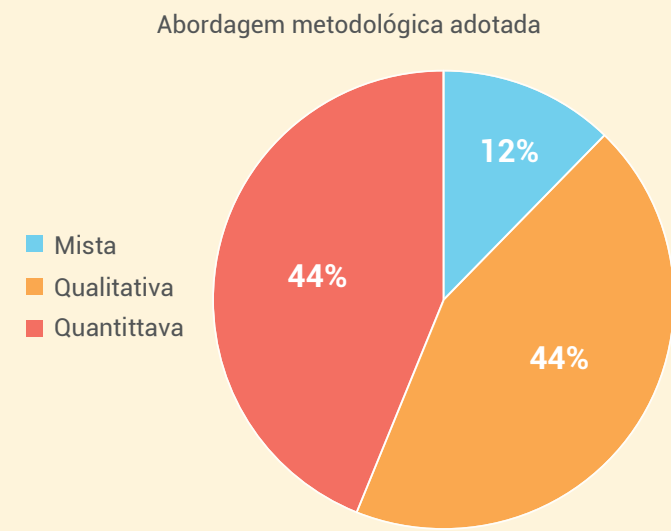

Fonte: DPJ/CNJ. Base: 57 trabalhos (teses e dissertações) com desenho empírico

Codificamos na sequência os temas tratados nesses trabalhos. 0 critério para essa codificação seguiu a lógica das atribuições do CNJ, observando se a preocupação do estudo está voltada para sua atribuição de gestão (gestão administrativa e financeira, assim como políticas judiciárias voltadas à defesa de direitos e garantias constitucionais), disciplinar (inspeção, correição, sindicância, reclamação disciplinar, representação por excesso de prazo, etc.), ou para aspectos do seu desenho institucional (criação e desenho do CNJ, perfil dos Conselheiros, imagem da instituição, questionamentos com relação a sua legitimidade democrática, etc.).

Percentual de trabalhos de acordo com tema

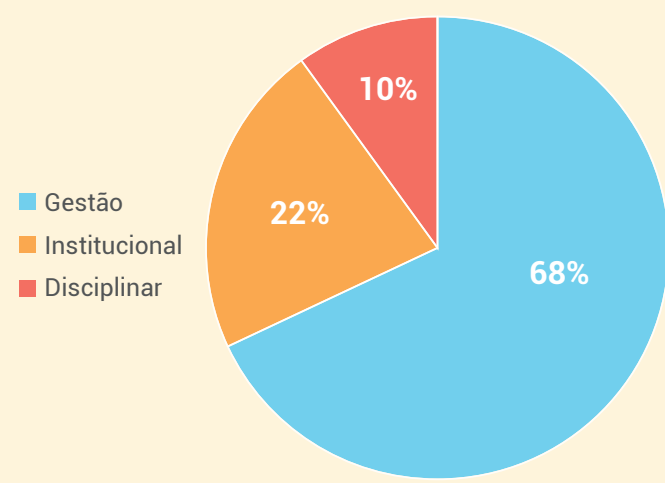

Fonte: DPJ/CNJ. Base: 115 trabalhos (teses e dissertações)

O tema mais recorrente é a gestão, correspondendo a $68 \%$ dos trabalhos, seguida da discussão de aspectos institucionais (22\%), referentes sobretudo ao desenho e instalação do Conselho, sendo ainda pouco explorada pela academia a dimensão disciplinar ( $10 \%$ dos trabalhos).

Quando consideramos a intersecção entre tema e centralidade do CNJ no estudo, observamos que as pesquisas sobre gestão são as que mais tratam o CNJ como objeto secundário, isso porque grande parte desses estudos é voltada à análise dos impactos de políticas judiciárias.

11. O fomento do CNJ deu-se via parceria com a CAPES em um acordo de cooperação a partir do Edital n. 20/2010/CAPES/CNJ. Esse edital selecionou onze projetos, contemplando 23 coordenadores de pesquisa, 61 estudantes de mestrado e 28 estudantes de doutorado. A cooperação previa financiamento dos coordenadores e auxilio financeiro a alunos regularmente matriculados em cursos de mestrado e doutorado que optassem por desenvolver suas dissertações e teses nos temas prioritários para o Judiciário, quais sejam : a) sistema de justiça criminal no Brasil; b) análise do desempenho dos órgãos do Poder Judiciário; c) aprimoramento dos instrumentos para uma prestação jurisdicional mais eficiente; $d$ ) atuação, competência e interfaces do CNJ com os demais órgãos do Poder Judiciário e dos outros poderes; e) utilização da tecnologia da informação para o aprimoramento do Poder Judiciário; f) principais problemas no processo de revisão das decisões nos Juizados Especiais Federais. 
Centralidade do CNJ no estudo, de acordo com o tema

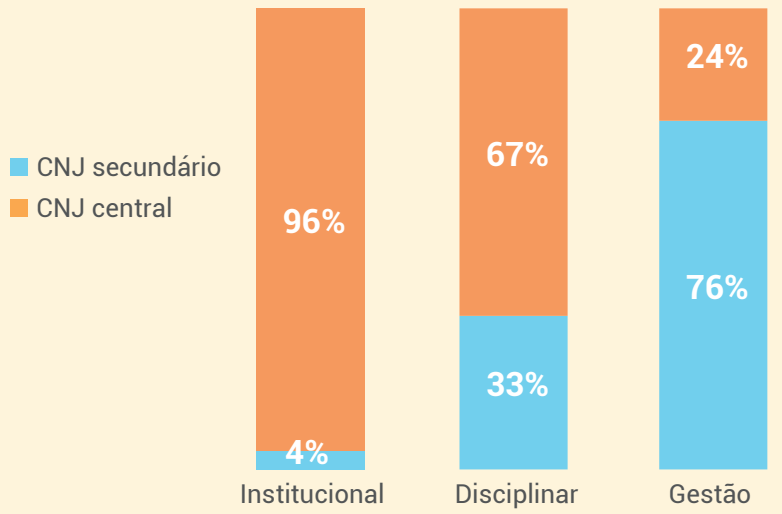

Fonte: DPJ/CNJ. Base: Institucional: 25 trabalhos (teses e dissertações); Disciplinar: 12 trabalhos (teses e dissertações); Gestão: 78 trabalhos (teses e dissertações).

Os três temas foram especificados em assuntos, sendo que o assunto mais abordado nesses trabalhos é o planejamento estratégico, com praticamente um quarto das pesquisas $(24 \%)$ privilegiando a investigação do papel do $\mathrm{CNJ}$ como indutor do planejamento estratégico e da modernização administrativa, havendo grande destaque para a política de metas e para a produção e uso de estatísticas judiciais.

O segundo assunto mais recorrente é a política judiciária referente aos meios consensuais (alternativos) de resolução de conflitos (ADR - $23 \%$ dos trabalhos tratam desse assunto).

Em terceiro lugar, aparece a discussão acerca da legitimidade democrática da criação e do desenho do CNJ, tratando do processo da tramitação e aprovação da EC 45/2004 e das contestações à constitucionalidade do Conselho no âmbito do STF.

Analisamos em detalhe os assuntos das pesquisas em cada tema. No tocante à gestão, as pesquisas exploram sobretudo os fatores organizacionais que interferem no desempenho do Judiciário e se voltam à busca por soluções para os principais problemas do Poder Judiciário.

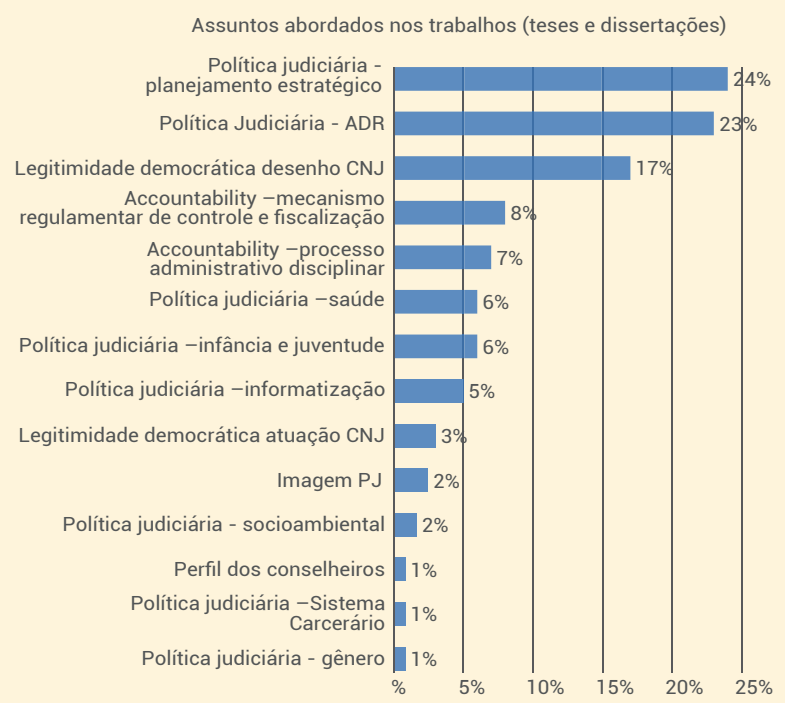

Fonte: DPJ/CNJ. Base: 115 trabalhos (teses e dissertações)
Os dois assuntos mais recorrentes no tema da gestão foram as políticas judiciárias de planejamento estratégico (36\%) e de mediação e conciliação - ADR (33\%).

As pesquisas que enfocam o planejamento estratégico, tratam principalmente da morosidade da justiça e da busca por soluções para esse problema. Enfatizam indicadores de mensuração do atraso na prestação jurisdicional e iniciativas do $\mathrm{CNJ}$ voltadas ao planejamento e gerenciamento da prestação do serviço jurisdicional.

Metade das pesquisas nesse assunto utilizou metodologia empírica, sobretudo análise de dados quantitativos de movimentação processual, havendo uma série de estudos de caso sobre a implementação de políticas de gestão estratégica em diferentes varas e comarcas.

Cerca de $10 \%$ dos trabalhos classificados no tema gestão abordaram a implementação da Resolução CNJ n. 70, de $18 / 03 / 2009$, que dispõe sobre o planejamento e a gestão estratégica no âmbito do Poder Judiciário, explorando a criação de indicadores de resultados e metas, e analisando o desempenho de diferentes tribunais e comarcas nesses indicadores ao longo do tempo. Outros $6 \%$ dedicam-se ao estudo da Resolução CNJ n. 76, de 12/05/2009, que dispõe sobre os princípios do Sistema de Estatística do Poder Judiciário, estabelece seus indicadores, fixa prazos, determina penalidades. Há ainda trabalhos que analisam as Tabelas Processuais Unificadas do Poder Judiciário, implementadas pela Resolução CNJ n. 46, de 18 de dezembro de 2007, que buscam propiciar uniformização taxonômica e terminológica de classes, assuntos e movimentação processuais.

Alguns trabalhos analisam os relatórios anuais do $\mathrm{CNJ}$ e outros utilizam os dados do Justiça em Números ${ }^{12}$ para verificar o desempenho do Poder Judiciário nacional em termos de estrutura e movimentação processual, destacando o papel do CNJ na indução do planejamento estratégico e na uniformização da atuação dos órgãos e agentes judiciários.

Há diagnósticos sobre o impacto e a efetividade da implementação dessas políticas, assim como problematizações de potenciais externalidades negativas das políticas de celeridade, como a do dilema "celeridade x qualidade".

O segundo assunto mais abordado na discussão da dimensão da gestão é a mediação e a conciliação, sendo que a Resolução CNJ n. 125, de 29/11/2010, que dispõe sobre a Política Judiciária Nacional de tratamento adequado dos conflitos de interesses no âmbito do Poder Judiciário, foi a mais estudada, aparecendo em quase um terço dos trabalhos sobre gestão (29\%).

Essa resolução estabelece em seu artigo primeiro, parágrafo único, que,

"Aos órgãos judiciários incumbe, nos termos do art. 334 do Novo Código de Processo Civil combinado com o art. 27 da Lei de Mediação, antes da solução adjudicada mediante sentença, oferecer outros mecanismos de soluções de controvérsias, em especial os chamados meios consensuais, como a mediação e a conciliação, bem assim prestar atendimento e orientação ao cidadão. (Redação dada pela Emenda $n^{\circ} 2$, de 08.03.16)"13

12. Todos os relatórios e dados do Justiça em Números estão de disponíveis em: http://www.cnj.jus.br/programas-e-acoes/pj-justica-em-numeros

13. Texto na íntegra disponivel em http://www.cnj.jus.br/busca-atos-adm?documento=2579. Acesso em 10/04/2017. 
Assuntos no tema Gestão

Planejamento estratégico
ADR
Infância e juventude
Saúde
Informatização
Socioambiental
Gênero
Sistema Carcerário

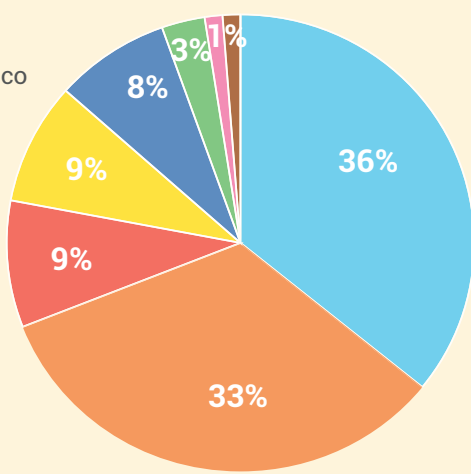

Fonte: DPJ/CNJ. Base: 78 trabalhos (teses e dissertações)

Alguns dos trabalhos sobre meios consensuais (alternativos) de resolução de conflitos fazem uma compilação de métodos em vigor no Brasil e em outros países, discutindo sua contribuição para combater a morosidade, consistindo em análises teórico-normativas e descritivas de diferentes modalidades. Mas a maioria das pesquisas nesse assunto (58\%) baseia-se em abordagens empíricas, tratando do impacto da política de tratamento adequado dos conflitos nos mecanismos institucionais de acesso à justiça no Estado, de avaliações de programas como o prêmio " Conciliar é Legal", do CNJ, e resultados práticos das semanas nacionais de conciliação.

Localizamos, ainda, pesquisas que abordam a inserção dos meios não adversariais de resolução de controvérsias no ensino, problematizando como o ensino do Direito incorpora a mediação e avaliando qual tem sido o impacto da Resolução CNJ n. 125/2010 nessa área. Nessa seara específica as conclusões apontam para a necessidade de readequação do ensino para incorporar tal mudança de orientação.

Outros assuntos que aparecem na dimensão da gestão são as políticas judiciárias no âmbito de infância e juventude, de saúde e de informatização.

Com relação à infância e juventude, os trabalhos se voltam à análise do Cadastro Nacional de Adoção e de políticas específicas como os programas "Pai Presente"14 e "Justiça ao Jovem"15.

No assunto saúde, classificamos as teses e dissertações que enfocam a atuação do CNJ na temática da tutela do direito à saúde, retratando o fenômeno da judicialização da saúde, com destaque para as análises dos impactos da Resolução CNJ n. 107, de 06 de abril de 2010, que instituiu o Fórum Nacional do Judiciário para monitoramento e resolução das demandas de assistência à saúde, e da Recomendação CNJ n. 31, de 30/03/2010, indicando aos tribunais a adoção de medidas de subsídio aos magistrados e demais operadores do direito, para assegurar maior eficiência na solução das demandas judiciais envolvendo a assistência à saúde.

No assunto política judiciária de informatização classificamos os trabalhos que analisam a implementação do Processo Judicial Eletrônico (PJe), considerando impactos e contribuições das ferramentas computacionais no aumento da produtividade.

A política ambiental no âmbito do Poder Judiciário foi objeto de dois trabalhos, que enfocaram a aplicação da Recomendação CNJ n. 11, de 22/05/2007, que orienta os tribunais a adotarem "políticas públicas visando à formação e recuperação de um ambiente ecologicamente equilibrado, além da conscientização dos próprios servidores e jurisdicionados sobre a necessidade de efetiva proteção ao meio ambiente, bem como instituam comissões ambientais para o planejamento, elaboração e acompanhamento de medidas, com fixação de metas anuais, visando à correta preservação e recuperação do meio ambiente"16.

Outros temas de gestão que apareceram de forma pontual foram a questão de gênero, num estudo voltado ao mapeamento das políticas de gênero nos atos normativos do CNJ e a política do CNJ para o sistema carcerário, numa análise de dados do Cadastro Nacional de Inspeções nos Estabelecimentos Penais (CNIEP), a partir da radiografia chamada "Geopresídios "17.

No tema institucional, o principal assunto abordado é a legitimidade democrática do desenho do CNJ, correspondendo a $76 \%$ dos trabalhos classificados no tema. A maioria das pesquisas vale-se de discussões teórico-normativas, sendo que apenas $26 \%$ dos trabalhos sobre o assunto têm base empírica. A principal discussão é a do controle externo do Poder Judiciário, com argumentos que entendem a criação do Conselho como uma estratégia voltada à correção de déficits de transparência e de eficiência do Poder Judiciário contrastados com argumentos que enxergam no Conselho uma violação aos princípios da autonomia e da independência do Poder Judiciário. 0 segundo assunto mais recorrente é a discussão da atuação do $\mathrm{CNJ}$, indagando se no exercício de suas atribuições o Conselho tem atuado de forma legítima, e, sobretudo, se tem preservado a independência jurisdicional. Esses trabalhos baseiam-se principalmente na análise dos atos normativos do CNJ.

Localizamos também estudos que investigam o perfil dos Conselheiros do CNJ e a imagem que o Conselho busca difundir via suas peças publicitárias e seus canais de comunicação com o público (páginas de transparência).

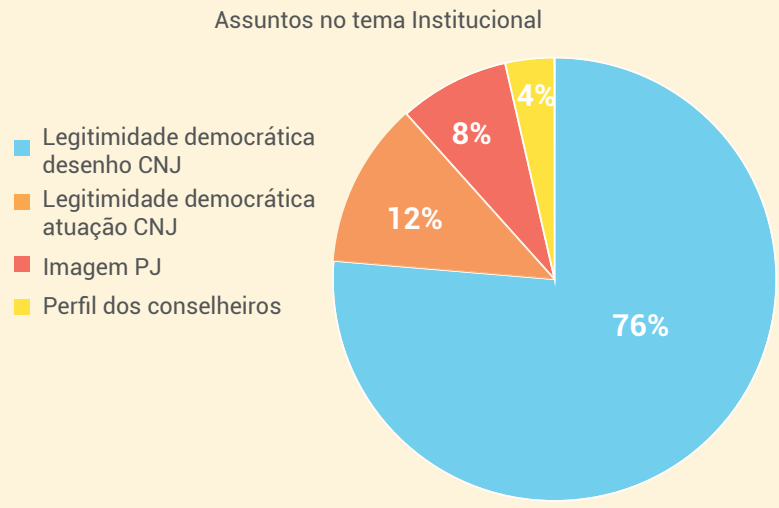

Fonte: DPJ/CNJ. Base: 25 trabalhos (teses e dissertações)

14. Instituído pelo Provimento n. 12, de 06 de agosto de 2010, da Corregedoria Nacional de Justiça, objetivando estimular o reconhecimento de paternidade de pessoas sem esse registro. Para mais informações sobre o programa, consultar. http://www.cnj.jus.br/programas-e-acoes/pai-presente. Acesso em 18/09/2017.

15. Programa do Departamento de Monitoramento e Fiscalização do Sistema Carcerário e do Sistema de Execução de Medidas Socioeducativas (DMF/CNJ), que buscou realizar uma radiografia nacional da execução de medidas socioeducativas de internação. Para mais informações sobre o programa, consultar. http:// buscou realizar uma radiografia nacional da execução de medidas socioeducativas de internação. Para mais informaçoes sobre o programa, consultar. http://
www.cnj.jus.br/atos-administrativos/atos-da-presidencia/264-acoes-e-programas/programas-de-a-a-z/justica-ao-jovem/13112-programa-justica-ao-jovem. www.cnj.jus.br/atos-adming
Acesso em 18/09/2017.

16. Ver integra da recomendação em: http://www.cnj.jus.br/atos-normativos?documento=867. Acesso em 19/04/2017

17. Disponivel em: http://www.cnj.jus.br/inspecao_penal/mapa.php. Acesso em 19/04/2017. 
No âmbito da atuação disciplinar do Conselho, a dimensão menos enfatizada pela academia, classificamos dois assuntos. 0 primeiro, accountability como mecanismo regulamentar de controle e fiscalização, reúne os trabalhos que analisam a atuação do Conselho, via resoluções no âmbito disciplinar e as inspeções e correições realizadas.

O segundo assunto, accountability como processo administrativo disciplinar, aborda os aspectos ligados ao exercício da competência disciplinar do $\mathrm{CNJ}$, agrupando os trabalhos que analisam os processos disciplinares sancionadores julgados pelo Conselho.

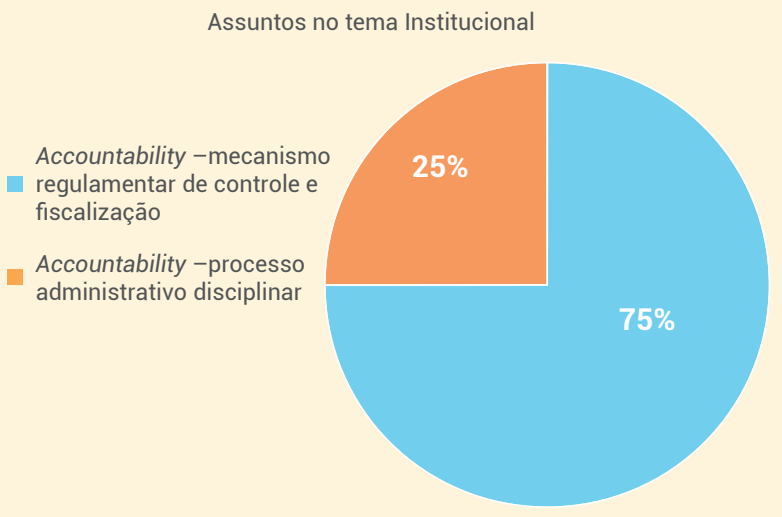

Fonte: DPJ/CNJ. Base: 12 trabalhos (teses e dissertações)

\section{Considerações finais}

$\mathrm{O}$ que essas pesquisas permitem concluir sobre os doze anos de atuação do CNJ?

De maneira geral, as pesquisas classificadas no tema Gestão mostram a valorização da instituição e o reconhecimento de que o Conselho vem imprimindo um novo modelo de gestão e governança ao Poder Judiciário, atuando no planejamento e implementação de ações, sobretudo voltadas para o combate à morosidade, como as políticas de metas, de mediação e conciliação e de informatização.

Identificam, também, os avanços em transparência e planejamento conquistados a partir dos dados produzidos pelo CNJ (sobretudo o Justiça em Números), que têm possibilitado uma melhor avaliação do desempenho das varas e dos Tribunais, permitindo diagnosticar os fatores que têm impactado sua performance, servindo, assim, à orientação de políticas judiciárias focadas na melhoria da prestação jurisdicional.

As conclusões caminham no sentido de afirmar a potencialidade dos dados para o diagnóstico da efetividade e da eficiência da prestação jurisdicional, sendo ainda pouco concernentes à dimensão da qualidade dessa prestação.

Na dimensão de gestão os estudos privilegiaram as áreas de atuação do CNJ que mais aproximam-se dos anseios da sociedade, como as ações de combate ao nepotismo e à morosidade.

Já as pesquisas classificadas no tema Institucional enfocam a discussão da criação e do desenho institucional do CNJ, abordando tanto a inserção do Conselho na discussão da Reforma do Judiciário, quanto sua instalação e o processo subsequente de questionamentos quanto a sua legitimidade constitucional, e mesmo ações que questionam no STF a constitucionalidade de resoluções do CNJ.

Em geral, essas pesquisas afirmam a legitimidade democrática do Conselho na medida que demonstram como ele imprime uma mudança no modelo de administração de justiça, localizando o CNJ como uma força inovadora que vem regulamentando, fiscalizando e construindo políticas públicas voltadas à celeridade e à eficiência organizacional. As pesquisas apontam, também, os embates e questionamentos à atuação do $\mathrm{CNJ}$, mapeando alguns segmentos corporativos que defendem uma atuação mais restrita, argumentando que a atuação mais expansiva do Conselho colocaria em xeque a independência da função judicial.

Por fim, no tema Disciplinar, as pesquisas evidenciaram a atuação fiscalizadora e disciplinar do $\mathrm{CNJ}$, analisando seu poder correcional e regulamentar ao estabelecer regras e limites e punir desvios de conduta. Essa área tem sido menos privilegiada pela academia, sobretudo no que se refere aos processos disciplinares, com as pesquisas debruçando-se sobre a análise de decisões jurisprudenciais disponíveis. Embora reconhecida sua atuação, algumas pesquisas apontam que o desempenho do poder disciplinar do Conselho é ainda restrito, sendo sua contribuição principalmente no âmbito de uniformização administrativa, mais do que no âmbito punitivo, até mesmo devido às limitações normativas de cunho sancionador. 
Lista de Teses e Dissertações Analisadas ${ }^{18}$

Tema: Gestão

\begin{tabular}{|c|c|c|c|c|}
\hline Ano & Título & Universidade & Nível & Autor \\
\hline 2008 & $\begin{array}{l}\text { Mecanismos de resolução alternativa de conflitos como } \\
\text { ferramenta de auxílio para construção da política judiciária no } \\
\text { Brasil }\end{array}$ & $\begin{array}{l}\text { Pontifícia Universidade } \\
\text { Católica do Paraná }\end{array}$ & Mestrado & $\begin{array}{l}\text { Fernandes Júnior, } \\
\text { Edson }\end{array}$ \\
\hline 2009 & $\begin{array}{l}\text { O Conselho Nacional de Justiça como instrumento de } \\
\text { minimização da morosidade processual }\end{array}$ & $\begin{array}{l}\text { Fundação de Ensino } \\
\text { Eurípides Soares da } \\
\text { Rocha }\end{array}$ & Mestrado & $\begin{array}{l}\text { Araújo, André Luís de } \\
\text { Toledo }\end{array}$ \\
\hline 2009 & $\begin{array}{l}\text { O controle externo do Poder Judiciário e a atuação do Conselho } \\
\text { Nacional de Justiça nos estados da federação: as propostas } \\
\text { atuais de gestão em Pernambuco e outros estados }\end{array}$ & $\begin{array}{l}\text { Universidade Federal de } \\
\text { Pernambuco }\end{array}$ & Mestrado & $\begin{array}{l}\text { Campos, Hélio } \\
\text { Cavalcanti de Siqueira }\end{array}$ \\
\hline 2009 & $\begin{array}{l}\text { Planejamento estratégico e mudança organizacional: o caso do } \\
\text { Tribunal Regional do Trabalho da } 3^{a} \text { Região }\end{array}$ & Fundação João Pinheiro & Mestrado & $\begin{array}{l}\text { Reis, Patrícia Helena } \\
\text { dos }\end{array}$ \\
\hline 2010 & Direito a um serviço público judiciário adequado & $\begin{array}{l}\text { Universidade Federal da } \\
\text { Bahia }\end{array}$ & Mestrado & $\begin{array}{l}\text { Almeida, Caê Matos } \\
\text { Teixeira de }\end{array}$ \\
\hline 2010 & $\begin{array}{l}\text { Política judiciária no Conselho Nacional de Justiça: e a } \\
\text { perspectiva de gênero? }\end{array}$ & $\begin{array}{l}\text { Fundação Getúlio Vargas } \\
\text { do Rio de Janeiro }\end{array}$ & Mestrado & $\begin{array}{l}\text { Lavigne, Rosane Maria } \\
\text { Reis }\end{array}$ \\
\hline 2010 & Planejamento estratégico em comarca do Poder Judiciário & $\begin{array}{l}\text { Fundação Getúlio Vargas } \\
\text { do Rio de Janeiro }\end{array}$ & Mestrado & Deolindo, Vanderlei \\
\hline 2011 & $\begin{array}{l}\text { O princípio da justiça social e a sua relação com o Conselho } \\
\text { Nacional de Justiça: uma análise das suas implicações na } \\
\text { justiça da infância e da juventude }\end{array}$ & $\begin{array}{l}\text { Universidade Federal de } \\
\text { Santa Catarina }\end{array}$ & Doutorado & Junkes, Sérgio Luiz \\
\hline 2011 & $\begin{array}{l}\text { Poder Judiciário e gestão: uma parceria de sucesso para } \\
\text { impulsionar a prestação jurisdicional Poder Judiciário e } \\
\text { gestão: uma parceria de sucesso para impulsionar a prestação } \\
\text { jurisdicional }\end{array}$ & $\begin{array}{l}\text { Pontifícia Universidade } \\
\text { Católica do Paraná }\end{array}$ & Mestrado & Stein Júnior, Irineu \\
\hline 2012 & Processo eletrônico como instrumento de acesso à justiça & $\begin{array}{l}\text { Universidade Estadual } \\
\text { Paulista }\end{array}$ & Mestrado & $\begin{array}{l}\text { Archiza, Ana Carolina } \\
\text { Fonseca Martinez Perez }\end{array}$ \\
\hline 2012 & Avaliação da qualidade de juizados especiais cíveis estaduais & Universidade Potiguar & Mestrado & $\begin{array}{l}\text { Oliveira, Heitor César } \\
\text { Costa de }\end{array}$ \\
\hline 2012 & $\begin{array}{l}\text { Processo Judicial Eletrônico: uma abordagem metodológica } \\
\text { para o processo de sua implementação }\end{array}$ & $\begin{array}{l}\text { Universidade de São } \\
\text { Paulo }\end{array}$ & Doutorado & $\begin{array}{l}\text { Martinez, Ramsés } \\
\text { Henrique }\end{array}$ \\
\hline 2012 & $\begin{array}{l}0 \text { fórum múltiplas portas como política pública de acesso à } \\
\text { justiça e a pacificação social }\end{array}$ & $\begin{array}{l}\text { Universidade de Santa } \\
\text { Cruz do Sul }\end{array}$ & Mestrado & $\begin{array}{l}\text { Oliveira, Luthyana } \\
\text { Demarchi de }\end{array}$ \\
\hline 2013 & $\begin{array}{l}\text { Atuação do Conselho Nacional de Justiça à luz dos modelos da } \\
\text { Administração Pública: uma análise do período de } 2005 \text { a } 2012\end{array}$ & Universidade de Brasília & Mestrado & Oliveira, Erika Neves \\
\hline 2013 & $\begin{array}{l}\text { Políticas públicas e meios não adversarias de resolução de } \\
\text { conflitos: política judiciária nacional da resolução } 125 \text { do } \\
\text { Conselho Nacional de Justiça e a Justiça do Trabalho }\end{array}$ & $\begin{array}{l}\text { Universidade de São } \\
\text { Paulo }\end{array}$ & Doutorado & $\begin{array}{l}\text { Moraes, Maria Isabel } \\
\text { Cueva }\end{array}$ \\
\hline 2013 & $\begin{array}{l}\text { As metas do Conselho Nacional de Justiça e os esforços de } \\
\text { planejamento estratégico no Tribunal de Justiça do estado do } \\
\text { Rio de Janeiro }\end{array}$ & $\begin{array}{l}\text { Fundação Getúlio Vargas } \\
\text { do Rio de Janeiro }\end{array}$ & Mestrado & $\begin{array}{l}\text { Branco, Luiza } \\
\text { Szczerbacki Castello }\end{array}$ \\
\hline 2013 & $\begin{array}{l}\text { O planejamento estratégico no Poder Judiciário e o } \\
\text { aperfeiçoamento na prestação jurisdicional }\end{array}$ & $\begin{array}{l}\text { Universidade Estadual do } \\
\text { Norte do Paraná }\end{array}$ & Mestrado & Fuin, Tatiane de Abreu \\
\hline 2013 & $\begin{array}{l}\text { Processo Judicial Eletrônico: política pública de virtualização } \\
\text { do Poder Judiciário }\end{array}$ & $\begin{array}{l}\text { Universidade Estadual } \\
\text { do Ceará }\end{array}$ & Mestrado & Brasil, Rebeca Ferreira \\
\hline 2013 & $\begin{array}{l}\text { A aproximação entre a mediação de conflitos e o Poder } \\
\text { Judiciário no estado do Ceará: atividades desencadeadas a } \\
\text { partir da resolução } n^{\circ} 125 \text { do Conselho Nacional de Justiça }\end{array}$ & $\begin{array}{l}\text { Universidade de } \\
\text { Fortaleza }\end{array}$ & Mestrado & $\begin{array}{l}\text { Chaves, Emmanuela } \\
\text { Carvalho Cipriano }\end{array}$ \\
\hline 2013 & $\begin{array}{l}\text { Conciliar é preciso: a implementação da política jurídica } \\
\text { nacional de tratamento adequado dos conflitos de interesses } \\
\text { no biênio } 2011-2013 \text { no estado do Ceará }\end{array}$ & $\begin{array}{l}\text { Universidade Estadual } \\
\text { do Ceará }\end{array}$ & Mestrado & $\begin{array}{l}\text { Barbosa Neto, Luiz } \\
\text { Alberto Gomes }\end{array}$ \\
\hline 2013 & $\begin{array}{l}\text { O Conselho Nacional de Justiça e as políticas da qualidade nos } \\
\text { tribunais de justiça do Brasil: um diálogo entre administração } \\
\text { judiciária e o tema do acesso à justiça }\end{array}$ & $\begin{array}{l}\text { Pontifícia Universidade } \\
\text { Católica do Rio de } \\
\text { Janeiro }\end{array}$ & Mestrado & $\begin{array}{l}\text { Sardinha, Flávia } \\
\text { Campos }\end{array}$ \\
\hline 2013 & A justiça restaurativa como via de acesso à justiça & $\begin{array}{l}\text { Universidade Federal de } \\
\text { Minas Gerais }\end{array}$ & Mestrado & $\begin{array}{l}\text { Lara, Caio Augusto } \\
\text { Souza }\end{array}$ \\
\hline 2013 & $\begin{array}{l}\text { A tutela do direito a saúde e a integração legislativa da } \\
\text { Constituição Federal: uma investigação de efetividade do Poder } \\
\text { Judiciário sob a ótica do Conselho Nacional de Justiça }\end{array}$ & $\begin{array}{l}\text { Pontifícia Universidade } \\
\text { Católica de São Paulo }\end{array}$ & Mestrado & $\begin{array}{l}\text { Mendes Neto, João } \\
\text { Paulo }\end{array}$ \\
\hline 2013 & $\begin{array}{l}\text { A razoável duração do processo na era das metas de } \\
\text { produtividade do Conselho Nacional de Justiça brasileiro }\end{array}$ & $\begin{array}{l}\text { Universidade do Vale do } \\
\text { Rio dos Sinos }\end{array}$ & Mestrado & $\begin{array}{l}\text { Bemvenuti, Cássio } \\
\text { Schneider }\end{array}$ \\
\hline 2014 & $\begin{array}{l}\text { Judicialização das políticas públicas e proteção e tutela do } \\
\text { direito fundamental a saúde: cerceamento do acesso à justiça } \\
\text { mediante a mitigação do interesse de agir pelos enunciados do } \\
\text { Conselho Nacional de Justiça }\end{array}$ & $\begin{array}{l}\text { Universidade de Ribeirão } \\
\text { Preto }\end{array}$ & Mestrado & Florêncio, Stella Villela \\
\hline 2015 & $\begin{array}{l}\text { Direito a saúde e judicialização: uma análise da atuação do } \\
\text { Conselho Nacional de Justiça no aprimoramento da prestação } \\
\text { jurisdicional nas demandas de saúde }\end{array}$ & $\begin{array}{l}\text { Universidade Federal do } \\
\text { Maranhão }\end{array}$ & Mestrado & Diniz, Isadora Moraes \\
\hline
\end{tabular}




\begin{tabular}{|c|c|c|c|c|}
\hline 2015 & $\begin{array}{l}\text { O fenômeno jurídico da conciliação: o Conselho Nacional de } \\
\text { Justiça, a Justiça do Trabalho e a sua efetividade }\end{array}$ & $\begin{array}{l}\text { Centro Universitário de } \\
\text { Curitiba }\end{array}$ & Mestrado & $\begin{array}{l}\text { Amaral, Carlos Alberto } \\
\text { Guimarães }\end{array}$ \\
\hline 2015 & $\begin{array}{l}\text { O controle do Conselho Nacional de Justiça sobre os Tribunais } \\
\text { de Justiça: o caso do Tribunal de Justiça do Piauí (TJ-PI) e } \\
\text { Tribunal de Justiça do Maranhão (TJ-MA) }\end{array}$ & $\begin{array}{l}\text { Universidade Federal do } \\
\text { Piauí }\end{array}$ & Mestrado & Paz, Vanessa Martins \\
\hline 2015 & $\begin{array}{l}\text { A implementação da mediação como política pública de } \\
\text { pacificação dos conflitos familiares por meio da resolução } n^{\circ} \\
125 \text { do Conselho Nacional de Justiça }\end{array}$ & $\begin{array}{l}\text { Universidade de Santa } \\
\text { Cruz do Sul }\end{array}$ & Mestrado & $\begin{array}{l}\text { Marcantonio, Roberta } \\
\text { Brasiliense }\end{array}$ \\
\hline 2015 & Improbidade administrativa no Brasil: uma análise de output & $\begin{array}{l}\text { Universidade Federal de } \\
\text { Alagoas }\end{array}$ & Mestrado & $\begin{array}{l}\text { Santos, Denisson da } \\
\text { Silva }\end{array}$ \\
\hline 2015 & $\begin{array}{l}\text { Juizado Especial Federal: contributo para um modelo } \\
\text { democrático de justiça conciliativa }\end{array}$ & $\begin{array}{l}\text { Universidade do Vale do } \\
\text { Rio dos Sinos }\end{array}$ & Doutorado & Vaz, Paulo Afonso Brum \\
\hline 2015 & $\begin{array}{l}\text { Da taxonomia a parametrização: Tabelas Processuais } \\
\text { Unificadas como mecanismo de padronização e celeridade da } \\
\text { prestação jurisdicional no Tocantins }\end{array}$ & $\begin{array}{l}\text { Universidade Federal do } \\
\text { Tocantins }\end{array}$ & Mestrado & $\begin{array}{l}\text { Stakoviak, Kellen Cleya } \\
\text { dos Santos Madalena }\end{array}$ \\
\hline 2015 & $\begin{array}{l}\text { As disfunções das noções gerais de direito e formação } \\
\text { humanística nos concursos para a magistratura: analise crítica } \\
\text { dos efeitos da resolução } n^{\circ} 75 \text { do Conselho Nacional de Justiça }\end{array}$ & Faculdade Meridional & Mestrado & Tusset, Igor Rocha \\
\hline 2009 & $\begin{array}{l}\text { Gestão ambiental na Administração Pública: sua } \\
\text { institucionalização no Tribunal Regional da } 5^{\circ} \text { Região }\end{array}$ & $\begin{array}{l}\text { Universidade Federal de } \\
\text { Pernambuco }\end{array}$ & Mestrado & Esteves, Deise Ferreira \\
\hline 2014 & $\begin{array}{l}\text { O Conselho Nacional de Justiça, o Processo Judicial Eletrônico, } \\
\text { as tecnologias de informação e as novas perspectivas para } \\
\text { administração da justiça brasileira }\end{array}$ & $\begin{array}{l}\text { Universidade Federal da } \\
\text { Bahia }\end{array}$ & Mestrado & $\begin{array}{l}\text { Godinho, Pedro Rogério } \\
\text { Castro }\end{array}$ \\
\hline 2014 & $\begin{array}{l}\text { Tribunal de Justiça do estado de Santa Catarina: uma análise } \\
\text { da gestão das metas do CNJ a partir das dimensões da } \\
\text { accountability de Koppell }\end{array}$ & $\begin{array}{l}\text { Universidade do Estado } \\
\text { de Santa Catarina }\end{array}$ & Mestrado & Bernieri, Juliana \\
\hline 2014 & $\begin{array}{l}\text { A efetividade do centro judiciário de solução de conflitos } \\
\text { (CEJUSC) como acesso à justiça }\end{array}$ & Universidade de Marília & Mestrado & $\begin{array}{l}\text { Evedove, Glória Regina } \\
\text { Dall }\end{array}$ \\
\hline 2014 & $\begin{array}{l}\text { Ciberdemocracia no Judiciário: uso de mapas como política de } \\
\text { virtualização }\end{array}$ & $\begin{array}{l}\text { Universidade Federal de } \\
\text { Santa Catarina }\end{array}$ & Doutorado & $\begin{array}{l}\text { Freire, Geovana Maria } \\
\text { Cartaxo de Arruda }\end{array}$ \\
\hline 2014 & $\begin{array}{l}\text { Crise social e Poder Judiciário: uma análise sociológica dos } \\
\text { quantitativos do CNJ sobre o judiciário brasileiro }\end{array}$ & $\begin{array}{l}\text { Universidade Cândido } \\
\text { Mendes }\end{array}$ & Mestrado & $\begin{array}{l}\text { Silva, Marcos Carnevale } \\
\text { Ignácio da }\end{array}$ \\
\hline 2015 & $\begin{array}{l}\text { Uma análise pragmática do programa pai presente do CNJ: } \\
\text { convergência entre as teorias de Pierce e James sobre a lógica } \\
\text { pragmática e a concepção de consequências práticas }\end{array}$ & $\begin{array}{l}\text { Universidade Federal da } \\
\text { Paraíba }\end{array}$ & Mestrado & $\begin{array}{l}\text { Guimarães, Luize Emile } \\
\text { Cardoso }\end{array}$ \\
\hline 2015 & $\begin{array}{l}\text { O meio ambiente de trabalho saudável dos magistrados como } \\
\text { direito fundamental: implicações da política de metas do } \\
\text { Conselho Nacional de Justiça }\end{array}$ & $\begin{array}{l}\text { Faculdade de Direito de } \\
\text { Vitória }\end{array}$ & Mestrado & $\begin{array}{l}\text { Silva, Elisete Regina } \\
\text { Meneghetti }\end{array}$ \\
\hline 2015 & $\begin{array}{l}\text { O ordenamento territorial da justiça trabalhista na região } \\
\text { centro-oeste: processo histórico e dinamismo territorial em } \\
\text { contraste ao incremento difuso do ramo de justiça trabalhista }\end{array}$ & Universidade de Brasília & Mestrado & Amiden Neto, Ganem \\
\hline 2015 & $\begin{array}{l}\text { Ensino jurídico e meios auto compositivos de resolução de } \\
\text { conflitos }\end{array}$ & $\begin{array}{l}\text { Universidade Federal } \\
\text { Fluminense }\end{array}$ & Doutorado & $\begin{array}{l}\text { Santos, Cibele Carneiro } \\
\text { da Cunha Macedo }\end{array}$ \\
\hline 2015 & $\begin{array}{l}\text { Mediação: a solução de conflitos trabalhistas individuais na } \\
\text { comissão de conciliação prévia à luz da ação comunicativa }\end{array}$ & $\begin{array}{l}\text { Universidade Federal do } \\
\text { Tocantins }\end{array}$ & Mestrado & Vieira, Murilo Braz \\
\hline 2015 & $\begin{array}{l}\text { Festa ou solenidade: limites e possibilidades de uma política } \\
\text { pública de acesso à justiça }\end{array}$ & $\begin{array}{l}\text { Universidade Católica de } \\
\text { Pelotas }\end{array}$ & Mestrado & $\begin{array}{l}\text { Freitas, Carmen Lúcia } \\
\text { Kaltbach Lemos de }\end{array}$ \\
\hline 2015 & $\begin{array}{l}\text { Reflexos da metabolização dos conflitos a partir da } \\
\text { implementação da mediação enquanto política pública no } \\
\text { Tribunal de Justiça do estado do Rio Grande do Sul, no tocante } \\
\text { aos servidores mediadores }\end{array}$ & $\begin{array}{l}\text { Universidade de Santa } \\
\text { Cruz do Sul }\end{array}$ & Mestrado & $\begin{array}{l}\text { Estivalet, Josiane } \\
\text { Caleffi }\end{array}$ \\
\hline 2016 & $\begin{array}{l}\text { Adoção de soluções em Online Dispute Resolution como } \\
\text { política pública para o Poder Judiciário: um panorama da } \\
\text { situação brasileira }\end{array}$ & $\begin{array}{l}\text { Universidade de } \\
\text { Fortaleza }\end{array}$ & Mestrado & $\begin{array}{l}\text { Lima, Gabriela } \\
\text { Vasconcelos }\end{array}$ \\
\hline 2016 & $\begin{array}{l}\text { Conselho Nacional de Justiça e os meios alternativos de } \\
\text { resolução de conflitos: avaliação da eficiência dos centros } \\
\text { judiciários de solução de conflitos na comarca de São Luís/MA }\end{array}$ & $\begin{array}{l}\text { Universidade Federal do } \\
\text { Maranhão }\end{array}$ & Mestrado & $\begin{array}{l}\text { Barbosa, Wermeson } \\
\text { Pinheiro }\end{array}$ \\
\hline 2016 & $\begin{array}{l}\text { Considerações sobre a resolução } \mathrm{CNJ}^{\circ}{ }^{\circ} \text { 125/2010: uma } \\
\text { avaliação política da política judiciaria brasileira: a solução dos } \\
\text { conflitos de interesses }\end{array}$ & $\begin{array}{l}\text { Universidade Federal do } \\
\text { Maranhão }\end{array}$ & Mestrado & $\begin{array}{l}\text { Aquino, Maria da Glória } \\
\text { Costa Gonçalves de } \\
\text { Sousa }\end{array}$ \\
\hline 2016 & $\begin{array}{l}\text { O papel do terceiro mediador na política pública brasileira de } \\
\text { tratamento de conflitos: resolução n } 125 \text { de } 29 \text { de novembro } \\
\text { de } 2010 \text { do Conselho Nacional de Justiça brasileiro: a luz } \\
\text { da experiência do modelo do tribunal de múltiplas portas do } \\
\text { distrito de Columbia, Estados Unidos da América }\end{array}$ & $\begin{array}{l}\text { Universidade de Santa } \\
\text { Cruz do Sul }\end{array}$ & Doutorado & $\begin{array}{l}\text { Gimenez, Charlise Paula } \\
\text { Colet }\end{array}$ \\
\hline 2016 & $\begin{array}{l}\text { O ensino jurídico e o tratamento adequado dos conflitos: } \\
\text { impacto da resolução } \mathrm{n}^{\circ} 125 \text { do CNJ sobre os cursos de Direito }\end{array}$ & $\begin{array}{l}\text { Universidade de São } \\
\text { Paulo }\end{array}$ & Mestrado & $\begin{array}{l}\text { Zamboni, Alex Alckmin } \\
\text { de Abreu Montenegro }\end{array}$ \\
\hline 2016 & $\begin{array}{l}\text { Análise econômica da eficiência do Poder Judiciário no } \\
\text { combate da corrupção: aplicações de métodos de fronteira } \\
\text { para os estados brasileiros 2003-2014 }\end{array}$ & $\begin{array}{l}\text { Universidade Estadual de } \\
\text { Maringá }\end{array}$ & Doutorado & $\begin{array}{l}\text { Botelho, Martinho } \\
\text { Martins }\end{array}$ \\
\hline 2016 & Conciliação judicial: uma abordagem crítica & $\begin{array}{l}\text { Universidade Católica de } \\
\text { Pernambuco }\end{array}$ & Mestrado & Morais, Luís Carlos de \\
\hline
\end{tabular}




\begin{tabular}{|c|c|c|c|c|}
\hline 2016 & $\begin{array}{l}\text { Gestão Ambiental no Poder Judiciário do estado do Tocantins: } \\
\text { análise do Tribunal de Justiça, com foco na educação } \\
\text { ambiental: propostas de educação ambiental }\end{array}$ & $\begin{array}{l}\text { Universidade Federal do } \\
\text { Tocantins }\end{array}$ & Mestrado & Souza, Leila Maria de \\
\hline 2016 & \begin{tabular}{|l|} 
Judicialização de políticas sociais como estratégia do Poder \\
Judiciário: o Fórum da Saúde e o Cadastro Nacional de Adoção
\end{tabular} & $\begin{array}{l}\text { Universidade Federal de } \\
\text { Pernambuco }\end{array}$ & Doutorado & $\begin{array}{l}\text { Santiago, Arthemisia } \\
\text { Ferreira Paulo }\end{array}$ \\
\hline 2016 & $\begin{array}{l}\text { O instituto da mediação e a reforma processual: uma análise } \\
\text { de casos da atuação do mediador no CEJUSC/RJ }\end{array}$ & $\begin{array}{l}\text { Universidade Católica de } \\
\text { Petrópolis }\end{array}$ & Mestrado & $\begin{array}{l}\text { Altoé, Bruna Fraga } \\
\text { Gonçalves }\end{array}$ \\
\hline 2008 & Processo e conciliação no estado democrático de direito & $\begin{array}{l}\text { Pontifícia Universidade } \\
\text { Católica de Minas Gerais }\end{array}$ & Mestrado & $\begin{array}{l}\text { Rodrigues, Ângela de } \\
\text { Lourdes }\end{array}$ \\
\hline 2010 & $\begin{array}{l}\text { A execução fiscal administrativa no Brasil, possível viabilidade } \\
\text { constitucional }\end{array}$ & $\begin{array}{l}\text { Universidade Católica de } \\
\text { Pernambuco }\end{array}$ & Mestrado & Silva, Carmina Alves \\
\hline 2011 & $\begin{array}{l}\text { O sistema judiciário brasileiro: evidências empíricas dos } \\
\text { incentivos ao litígio }\end{array}$ & $\begin{array}{l}\text { Fundação Getúlio Vargas } \\
\text { de São Paulo }\end{array}$ & Mestrado & $\begin{array}{l}\text { Miranda, Rachel de } \\
\text { Castro } \\
\end{array}$ \\
\hline 2014 & $\begin{array}{l}\text { Eu, os outros e o Judiciário: inteligibilidades das formas de } \\
\text { resolução de conflitos e relações sociais contemporâneas em } \\
\text { acesso à justiça no Brasil }\end{array}$ & $\begin{array}{l}\text { Universidade Estadual de } \\
\text { Montes Claros }\end{array}$ & Mestrado & $\begin{array}{l}\text { Santos, Claudemy } \\
\text { Correia dos }\end{array}$ \\
\hline 2014 & $\begin{array}{l}\text { A ação coletiva como instrumento de tutela e concretização do } \\
\text { direito a saúde }\end{array}$ & $\begin{array}{l}\text { Universidade de Ribeirão } \\
\text { Preto }\end{array}$ & $\mathrm{Me}$ & Bar \\
\hline 2014 & $\begin{array}{l}\text { A conciliação à luz do princípio constitucional da fraternidade: } \\
\text { a experiência da Justiça Federal da Primeira Região }\end{array}$ & $\begin{array}{l}\text { Pontifícia Universidade } \\
\text { Católica de São Paulo }\end{array}$ & Mestrado & $\begin{array}{l}\text { Fonseca, Reynaldo } \\
\text { Soares da }\end{array}$ \\
\hline 2014 & $\begin{array}{l}\text { A utilização das parcerias público privadas na consecução de } \\
\text { serviços carcerários: um estudo do complexo penitenciário } \\
\text { PPP na cidade de Ribeirão das Neves MG }\end{array}$ & $\begin{array}{l}\text { Universidade Federal de } \\
\text { Alfenas }\end{array}$ & Mestrado & $\begin{array}{l}\text { Santos, Jeferson Alves } \\
\text { dos }\end{array}$ \\
\hline 2014 & $\begin{array}{l}\text { A compreensão de diferentes atores sociais acerca das } \\
\text { medidas socioeducativas }\end{array}$ & Universidade de Brasília & Doutorado & $\begin{array}{l}\text { Araújo, Josilene Santos } \\
\text { de }\end{array}$ \\
\hline 2014 & $\begin{array}{l}\text { Estudos sobre o desempenho da primeira instância da Justiça } \\
\text { Estadual no Brasil }\end{array}$ & $\begin{array}{l}\text { Universidade Federal de } \\
\text { Pernambuco }\end{array}$ & Mestrado & $\begin{array}{l}\text { Gomes, Ademir de } \\
\text { Oliveira }\end{array}$ \\
\hline 2014 & $\begin{array}{l}\text { Impacto econômico da judicialização da política de assistência } \\
\text { farmacêutica no Brasil: o estado da arte }\end{array}$ & $\begin{array}{l}\text { Universidade Federal de } \\
\text { Pernambuco }\end{array}$ & Mestrado & Lin She Pin \\
\hline 2014 & $\begin{array}{l}\text { Judicialização do direito a saúde no estado do Ceará, Brasil: } \\
\text { cenários e desafios }\end{array}$ & $\begin{array}{l}\text { Universidade Federal do } \\
\text { Ceará }\end{array}$ & Mestrado & $\begin{array}{l}\text { Nunes, Carlos Francisco } \\
\text { Oliveira }\end{array}$ \\
\hline 2015 & $\begin{array}{l}\text { Óbices processuais a efetividade da tutela coletiva dos direitos } \\
\text { previdenciários }\end{array}$ & $\begin{array}{l}\text { Universidade Metodista } \\
\text { de Piracicaba }\end{array}$ & Mestrado & $\begin{array}{l}\text { Rocha, Rafaela da } \\
\text { Fonseca Lima }\end{array}$ \\
\hline 2015 & Formação de mediadores: um estudo no judiciário do Ceará & $\begin{array}{l}\text { Universidade de } \\
\text { Fortaleza }\end{array}$ & Mestrado & Bordoni, Jovina Dávila \\
\hline 2015 & $\begin{array}{l}\text { Medidas socioeducativas: doutrina da } \\
\text { modos de trabalho das unidades educ }\end{array}$ & $\begin{array}{l}\text { Universidade Catc } \\
\text { Dom Bosco }\end{array}$ & Mestrado & Silva, Valdeir \\
\hline 2015 & $\begin{array}{l}\text { A possibilidade da concretização da função social do estado } \\
\text { contemporâneo com a utilização de meios alternativos de } \\
\text { resolução de conflitos na jurisdição brasileira }\end{array}$ & $\begin{array}{l}\text { Universidade do Vale do } \\
\text { Itajaí }\end{array}$ & Doutorado & Silva, Carlos Roberto da \\
\hline 2015 & $\begin{array}{l}\text { Para além da jurisdição dos conceitos sem coisas: o problema } \\
\text { da abstrativização da prestação jurisdicional a partir da análise } \\
\text { acerca da litigiosidade no Brasil }\end{array}$ & $\begin{array}{l}\text { Universidade do } \\
\text { Rio dos Sinos }\end{array}$ & Doutorado & $\begin{array}{l}\text { Santos, Karinne } \\
\text { Emanoela Goettems dos }\end{array}$ \\
\hline 2016 & $\begin{array}{l}\text { O poder judiciário na efetivação de direitos sociais: implicações } \\
\text { a separação de poderes }\end{array}$ & $\begin{array}{l}\text { Universidade de São } \\
\text { Paulo }\end{array}$ & Mestrado & Caliman, Pedro Augusto \\
\hline 2016 & $\begin{array}{l}\text { A importância das equipes multidisciplinares para o juízo da } \\
\text { infância e juventude no estado do Tocantins }\end{array}$ & $\begin{array}{l}\text { Universidade Federal do } \\
\text { Tocantins }\end{array}$ & Mestrado & $\begin{array}{l}\text { Vêncio Filho, Esmar } \\
\text { Custódio }\end{array}$ \\
\hline 2016 & $\begin{array}{l}\text { Judiciário, política e desenvolvimento: uma análise dos litígios } \\
\text { e das estruturas do Poder Judiciário brasileiro }\end{array}$ & $\begin{array}{l}\text { Universidade } \\
\text { Presbiteriana Mackenzie }\end{array}$ & Mestrado & Rosalen, Volnei \\
\hline 2016 & $\begin{array}{l}\text { O Judiciário Federal no combate a corrupção: uma análise da } \\
\text { efetividade no julgamento das ações anticorrupção no período } \\
\text { de } 2010 \text { a } 2014\end{array}$ & $\begin{array}{l}\text { Universidade Federal do } \\
\text { Pará }\end{array}$ & Mestrado & Pamplona, Erika Souza \\
\hline 2016 & $\begin{array}{l}\text { Adolescentes institucionalizados(as) em situação de exclusão } \\
\text { na cidade de Salvador: uma investigação social e étnica sob o } \\
\text { prisma dos Direitos Humanos }\end{array}$ & $\begin{array}{l}\text { Universidade Católica de } \\
\text { Salvador }\end{array}$ & Mestrado & $\begin{array}{l}\text { Santana, Gilton Carlos } \\
\text { da Silva }\end{array}$ \\
\hline 2016 & $\begin{array}{l}\text { Desjudicialização da execução fiscal e eficiência na gestão } \\
\text { econômico tributária: novos paradigmas para o Poder } \\
\text { Judiciário }\end{array}$ & $\begin{array}{l}\text { Universidade Nove de } \\
\text { Julho }\end{array}$ & Mestrado & $\begin{array}{l}\text { Rakauskas, Sérgio } \\
\text { Ricardo Caires }\end{array}$ \\
\hline
\end{tabular}

\section{Tema: Institucional}

\begin{tabular}{|c|l|l|l|l|}
\hline Ano & \multicolumn{1}{|c|}{ Título } & \multicolumn{1}{|c|}{ Universidade } & \multicolumn{1}{c|}{ Nível } & \multicolumn{1}{c|}{ Autor } \\
\hline 2006 & $\begin{array}{l}\text { O Conselho Nacional de Justiça: a função jurisdicional e seu } \\
\text { déficit de legitimidade na Constituição Brasileira }\end{array}$ & $\begin{array}{l}\text { Universidade Federal da } \\
\text { Bahia }\end{array}$ & Mestrado & $\begin{array}{l}\text { Góes, Mauricio Dantas } \\
\text { Góes e }\end{array}$ \\
\hline 2006 & $\begin{array}{l}\text { O direito fundamental à jurisdição: Conselho Nacional de Justiça: } \\
\text { órgão controlador do poder jurídico e a busca por uma jurisdição } \\
\text { mais eficiente }\end{array}$ & Centro Universidade FIEO & Mestrado & Thurler Júnior, Hélio \\
\hline 2007 & $\begin{array}{l}\text { Controle do Judiciário: da expectativa a concretização: o primeiro } \\
\text { biênio do Conselho Nacional de Justiça }\end{array}$ & Universidade de Fortaleza & Mestrado & Uchôa, Marcelo Ribeiro \\
\hline 2008 & O Conselho Nacional de Justiça: um estudo da função normativa & $\begin{array}{l}\text { Universidade do Vale do } \\
\text { Itajaí }\end{array}$ & Mestrado & $\begin{array}{l}\text { Machado, Natália } \\
\text { Gaspar }\end{array}$ \\
\hline 2009 & O poder regulamentar do Conselho Nacional de Justiça & $\begin{array}{l}\text { Faculdades Integradas } \\
\text { do Brasil }\end{array}$ & Mestrado & $\begin{array}{l}\text { Schwartz, Hamilton } \\
\text { Rafael Marins }\end{array}$ \\
\hline
\end{tabular}




\begin{tabular}{|c|c|c|c|c|}
\hline 2010 & $\begin{array}{l}\text { Independência e integridade: o Conselho Nacional de Justiça e a } \\
\text { nova condição da política judicial no Brasil }\end{array}$ & Universidade de Brasília & Doutorado & Guerra, Gustavo Rabay \\
\hline 2010 & $\begin{array}{l}\text { O Conselho Nacional de Justiça e o controle democrático do Poder } \\
\text { Judiciário: uma realidade possível? }\end{array}$ & Universidade de Fortaleza & Mestrado & $\begin{array}{l}\text { Deocleciano, Pedro } \\
\text { Rafael Malveira }\end{array}$ \\
\hline 2010 & $\begin{array}{l}\text { O Conselho Nacional de Justiça e a cultura política brasileira: entre } \\
\text { o controle do estado e o poder nas relações sociais }\end{array}$ & $\begin{array}{l}\text { Universidade Federal de } \\
\text { Sergipe }\end{array}$ & Mestrado & Oliveira, Vitor Costa \\
\hline 2011 & $\begin{array}{l}\text { A jurisdição constitucional e o Conselho Nacional de Justiça: a } \\
\text { possibilidade do exercício do controle de constitucionalidade pelo } \\
\text { CNJ }\end{array}$ & $\begin{array}{l}\text { Universidade Católica de } \\
\text { Pernambuco }\end{array}$ & Mestrado & Fluhr, Fernanda Adriano \\
\hline 2011 & $\begin{array}{l}\text { Uma análise do discurso publicitário do Conselho Nacional de } \\
\text { Justiça }\end{array}$ & $\begin{array}{l}\text { Universidade do Grande } \\
\text { Rio }\end{array}$ & Mestrado & $\begin{array}{l}\text { Lodi, Marluce Dantas de } \\
\text { Freitas }\end{array}$ \\
\hline 2012 & Poder normativo do Conselho Nacional de Justiça & $\begin{array}{l}\text { Universidade } \\
\text { Presbiteriana Mackenzie }\end{array}$ & Doutorado & Lima, Robson Barbosa \\
\hline 2013 & $\begin{array}{l}\text { Quem controla o Judiciário: uma análise sobre o perfil dos } \\
\text { membros do Conselho Nacional de Justiça: } 2005-2011\end{array}$ & $\begin{array}{l}\text { Universidade Federal de } \\
\text { Pernambuco }\end{array}$ & Mestrado & $\begin{array}{l}\text { Costa Filho, José } \\
\text { Vinícius da }\end{array}$ \\
\hline 2013 & $\begin{array}{l}\text { A caixa-preta vs. o controle demagógico: os discursos dos } \\
\text { favoráveis e dos contrários à criação do CNJ }\end{array}$ & $\begin{array}{l}\text { Fundação Getúlio Vargas } \\
\text { do Rio de Janeiro }\end{array}$ & Mestrado & Castro, Tatiana de Souza \\
\hline 2014 & $\begin{array}{l}\text { Conselho Nacional de Justiça e sociedade: gestão participativa e } \\
\text { controle judiciário }\end{array}$ & $\begin{array}{l}\text { Universidade } \\
\text { Presbiteriana Mackenzie }\end{array}$ & Mestrado & $\begin{array}{l}\text { Silva, Camila Pellegrino } \\
\text { Ribeiro da }\end{array}$ \\
\hline 2014 & $\begin{array}{l}0 \text { Conselho Nacional de Justiça a partir do modo de regulação } \\
\text { brasileiro nos pós fordismo }\end{array}$ & \begin{tabular}{|l|} 
Universidade \\
Presbiteriana Mackenzie
\end{tabular} & Mestrado & Garducci, Letícia Galan \\
\hline 2014 & $\begin{array}{l}\text { Os limites do poder regulamentar do Conselho Nacional de Justiça } \\
\text { no contexto do Estado constitucional brasileiro }\end{array}$ & $\begin{array}{l}\text { Universidade Federal do } \\
\text { Rio Grande do Norte }\end{array}$ & rado & Silva, De \\
\hline 2014 & $\begin{array}{l}\text { CNJ e judicialização: o reconhecimento do poder de atuação do } \\
\text { CNJ pelo STF e suas consequências na judicialização }\end{array}$ & \begin{tabular}{|l} 
Pontifícia Universidade \\
Católica de São Paulo \\
\end{tabular} & Mestrado & Lima, Priscilla da Costa \\
\hline 2014 & O CNJ e a reconfiguração do campo judiciário & $\begin{array}{l}\text { Universidade Cândido } \\
\text { Mendes }\end{array}$ & Mestrado & $\begin{array}{l}\text { Werner, José Guilherme } \\
\text { Vasi }\end{array}$ \\
\hline 2014 & $\begin{array}{l}\text { A reforma de gestão no Poder Judiciário do Rio de Janeiro: como } \\
\text { os magistrados interpretam o papel exercido pelo CNJ }\end{array}$ & $\begin{array}{l}\text { Fundação Getúlio Vargas } \\
\text { do Rio de Janeiro }\end{array}$ & Mestrado & $\begin{array}{l}\text { Souza, Karin Merz } \\
\text { Fernandes de }\end{array}$ \\
\hline 2015 & $\begin{array}{l}\text { Atuação do Conselho Nacional de Justiça e independência } \\
\text { jurisdicional: interfaces e interferências }\end{array}$ & \begin{tabular}{|l} 
Pontifícia Universidade \\
Católica de São Paulo \\
\end{tabular} & Doutorado & \begin{tabular}{|l} 
Moreira, Diogo Rais \\
Rodrigues
\end{tabular} \\
\hline 2015 & $\begin{array}{l}\text { Dimensões operacionais nas relações extrajudiciais e } \\
\text { interinstitucionais do Conselho Nacional de Justiça }\end{array}$ & $\begin{array}{l}\text { Pontifícia Universidade } \\
\text { Católica de São Paulo }\end{array}$ & Doutorado & $\begin{array}{l}\text { Lazari, Rafael José } \\
\text { Nadim de }\end{array}$ \\
\hline 2015 & $\begin{array}{l}\text { Os limites constitucionais de atuação do Conselho Nacional de } \\
\text { Justiça }\end{array}$ & $\begin{array}{l}\text { Universidade de São } \\
\text { Paulo }\end{array}$ & Mestrado & Bossler, Fábio Luís \\
\hline 2015 & $\begin{array}{l}\text { Controle democrático do Poder Judiciário: o processo político e o } \\
\text { papel dos atores na criação do Conselho Nacional de Justiça }\end{array}$ & $\begin{array}{l}\text { Universidade Federal do } \\
\text { ABC }\end{array}$ & Mestrado & Silva, Patrícia Schoeps \\
\hline 2016 & $\begin{array}{l}\text { A administração da Justiça no Brasil e suas tendências } \\
\text { paradoxais: influências dos matizes hegemônico e contra } \\
\text { hegemônico no Poder Judiciário }\end{array}$ & $\begin{array}{l}\text { Universidade Federal de } \\
\text { Minas Gerais }\end{array}$ & Mestrado & $\begin{array}{l}\text { Vieira, Luana Roussin } \\
\text { Brasil }\end{array}$ \\
\hline 2016 & $\begin{array}{l}\text { Democracia e transparência pública: um estudo multicaso sobre } \\
\text { a efetividade das páginas de transparência de três órgãos públicos }\end{array}$ & $\begin{array}{l}\text { Universidade Federal de } \\
\text { Mato Grosso do Sul }\end{array}$ & Mestrado & $\begin{array}{l}\text { Gonçalves, Amadeu } \\
\text { Rodrigues }\end{array}$ \\
\hline
\end{tabular}

\section{Tema: Disciplinar}

\begin{tabular}{|c|c|c|c|c|}
\hline Ano & Título & Universidade & Nível & Autor \\
\hline 2008 & $\begin{array}{l}\text { O Conselho Nacional de Justiça como instrumento de } \\
\text { accountability horizontal }\end{array}$ & $\begin{array}{l}\text { Universidade de } \\
\text { Brasilia }\end{array}$ & Mestrado & $\begin{array}{l}\text { Rodrigues, Leandro do } \\
\text { Nascimento }\end{array}$ \\
\hline 2009 & $\begin{array}{l}\text { Conselho Nacional de Justiça: limitações à atuação do órgão de } \\
\text { controle do Poder Judiciário no Brasil }\end{array}$ & $\begin{array}{l}\text { Universidade Federal } \\
\text { de Pernambuco }\end{array}$ & Mestrado & Malta, Carolina Souza \\
\hline 2009 & $\begin{array}{l}\text { A atuação do Conselho Nacional de Justiça na aproximação entre } \\
\text { Poder Judiciário e sociedade }\end{array}$ & $\begin{array}{l}\text { Pontifícia Universidade } \\
\text { Católica do Paraná }\end{array}$ & Mestrado & $\begin{array}{l}\text { Alves, Carolina Fátima de } \\
\text { Souza }\end{array}$ \\
\hline 2009 & $\begin{array}{l}\text { A atribuição regulamentar do Conselho Nacional de Justiça: um } \\
\text { estudo sobre a concretização normativa (in)direta da constituição } \\
\text { da república brasileira em nível regulamentar }\end{array}$ & $\begin{array}{l}\text { Pontifícia Universidade } \\
\text { Católica de Minas } \\
\text { Gerais }\end{array}$ & Mestrado & Soares, Christiane Vieira \\
\hline 2011 & $\begin{array}{l}\text { O estado de papel construído num cenário de sangue e violência: } \\
\text { Algumas tentativas de combate a grilagem e pacificação social no } \\
\text { campo no estado do Pará }\end{array}$ & $\begin{array}{l}\text { Universidade Federal } \\
\text { do Pará }\end{array}$ & Mestrado & Santos, Gracilda Leão dos \\
\hline 2014 & $\begin{array}{l}\text { O controle disciplinar da magistratura e o perfil ético do } \\
\text { magistrado }\end{array}$ & $\begin{array}{l}\text { Universidade Federal } \\
\text { do Rio Grande do Sul }\end{array}$ & Doutorado & $\begin{array}{l}\text { Martins Filho, Ives Gandra } \\
\text { da Silva }\end{array}$ \\
\hline 2015 & $\begin{array}{l}\text { Como são julgados os juízes: uma análise do controle disciplinar } \\
\text { do Conselho Nacional de Justiça: } 2005-2013\end{array}$ & \begin{tabular}{|l} 
Fundação Getúlio \\
Vargas São Paulo
\end{tabular} & Mestrado & $\begin{array}{l}\text { Franco, Ivan Cândido da } \\
\text { Silva de }\end{array}$ \\
\hline 2015 & $\begin{array}{l}\text { A governança judicial do Conselho Nacional de Justiça nos } \\
\text { Tribunais de Justiça Estaduais da Região Norte de } 2009 \text { a } 2012\end{array}$ & $\begin{array}{l}\text { Universidade Federal } \\
\text { do Pará }\end{array}$ & Mestrado & $\begin{array}{l}\text { Lima, João Fernando } \\
\text { Pereira }\end{array}$ \\
\hline 2015 & $\begin{array}{l}\text { A regulação dos serviços notariais e registrais: o caso europeu e a } \\
\text { análise de formas de regulação }\end{array}$ & $\begin{array}{l}\text { Universidade do Vale } \\
\text { do Itajaí }\end{array}$ & Mestrado & Matoso, Everson Luís \\
\hline 2016 & $\begin{array}{l}\text { A conduta judicial ética teórica e aplicada contida em princípios e } \\
\text { regras deontológicos abrangidos pelo sistema constitucional }\end{array}$ & $\begin{array}{l}\text { Universidade Federal } \\
\text { do Rio Grande do } \\
\text { Norte }\end{array}$ & Mestrado & Araújo, Everton Amaral de \\
\hline 2008 & $\begin{array}{l}\text { A dignidade da pessoa humana e os princípios constitucionais do } \\
\text { processo do contraditório e celeridade processual }\end{array}$ & $\begin{array}{l}\text { Pontifícia Universidade } \\
\text { Católica do Rio de } \\
\text { Janeiro }\end{array}$ & Mestrado & $\begin{array}{l}\text { Duarte, Taciana Nogueira } \\
\text { de Carvalho }\end{array}$ \\
\hline
\end{tabular}




\section{Referências}

BRASIL. Conselho Nacional de Justiça. Resolução CNJ n. 7, de 18 de outubro de 2005. Disciplina o exercício de cargos, empregos e funções por parentes, cônjuges e companheiros de magistrados e de servidores investidos em cargos de direção e assessoramento, no âmbito dos órgãos do Poder Judiciário e dá outras providências. Disponível em: < http://www.cnj.jus.br/images/stories/ docs_cnj/resolucao/rescnj_07.pdf>

BRASIL. Conselho Nacional de Justiça. Resolução CNJ n. 46, de 18 de dezembro de 2007. Cria as Tabelas Processuais Unificadas do Poder Judiciário e dá outras providências. Disponível em: <http://www. cnj.jus.br///images/atos_normativos/resolucao/ resolucao_46_18122007_29042014165333.pdf>

BRASIL. Conselho Nacional de Justiça. Resolução CNJ n. 70, de 18 de março de 2009. Dispõe sobre o Planejamento e a Gestão Estratégica no âmbito do Poder Judiciário e dá outras providências. Disponível em: < http://www.cnj.jus. $\mathrm{br} /$ busca-atos-adm?documento $=2806>$.

BRASIL. Conselho Nacional de Justiça. Resolução CNJ n. 76, de 12 de maio de 2009. Dispõe sobre os princípios do Sistema de Estatística do Poder Judiciário, estabelece seus indicadores, fixa prazos, determina penalidades e dá outras providências. Disponível em: <http:// www.cnj.jus.br///images/atos_normativos/resolucao/ resolucao_76_12052009_10102012220048.pdf>.

BRASIL. Conselho Nacional de Justiça. Resolução CNJ n. 125, de 29 de novembro de 2010. Dispõe sobre a Política Judiciária Nacional de tratamento adequado dos conflitos de interesses no âmbito do Poder Judiciário e dá outras providências. Disponível em: <http://www. cnj.jus.br///images/atos_normativos/resolucao/ resolucao_125_29112010_16092014165812.pdf>.

BRASIL. Conselho Nacional de Justiça. Resolução CNJ n. $\mathbf{1 7 5}$, de 14 de maio de 2013. Cria as Tabelas Dispõe sobre a habilitação, celebração de casamento civil, ou de conversão de união estável em casamento, entre pessoas de mesmo sexo. Disponível em: < http://www.cnj.jus.br/ busca-atos-adm?documento $=2504>$.

BRASIL. Constituição (1988). Constituição da República Federativa do Brasil: texto constitucional promulgado em 5 de outubro de 1988, com as alterações adotadas pelas Emendas Constitucionais ns. 1/1992 a 86/2015, pelo Decreto Legislativo ns 186/2008 e pelas Emendas constitucionais de revisão ns. 1 a 6/1994. Brasília: Câmara dos Deputados, Edições Câmara, 2015. 112 p.
BRASIL. Constituição (1988). Emenda constitucional n. 45, de 30 de dezembro de 2004. Altera dispositivos dos arts. $5^{\circ}, 36,52,92,93,95,98,99,102,103,104,105,107,109$, $111,112,114,115,125,126,127,128,129,134$ e 168 da Constituição Federal, e acrescenta os arts. 103-A, 103B, 111-A e 130-A, e dá outras providências. Disponível em: <http://www.planalto.gov.br/ccivil_03/Constituicao/ Emendas/Emc/emc45.htm>

BRASIL. Corregedoria Nacional de Justiça. Provimento CNJ n. 12, de 6 de agosto de 2010. Disponível em: < http://cgj. tjrj.jus.br/documents/1017893/1294906/pai+presenteprovimento+CNJ-12-2010.pdf>

BRASIL. Supremo Tribunal Federal. ADI n. 3.367-1/ DF. Ação Direta de Inconstitucionalidade. Relator: Min. Cezar Peluso. Brasília, 13 de abril de 2005. Disponível em: $\quad<$ http://redir.stf.jus.br/paginadorpub/paginador. jsp?docTP=AC\&docID=363371.

RENAULT, S. R. T.; BOTTINNI, P. Reforma do Judiciário. São Paulo: Saraiva, 2005.

SADEK, M. T. CNJ: o futuro na agenda. In: Gilmar Ferreira Mendes; Fabiano Martins Silveira; Marco Aurélio Marrafon. (Org.). Conselho Nacional de Justiça - fundamentos, processo e gestão. São Paulo: Saraiva, 2016, p. 109-124.

SADEK, M. T. CNJ: impactos no Judiciário e na sociedade. In: Stoco, Rui; Penalva, Janaína. (Org.). Dez Anos de Reforma do Judiciário e o nascimento do Conselho Nacional de Justiça. São Paulo: Editora Revista dos Tribunais, 2015, v. 1, p. 293-312.

\section{Fabiana Luci de Oliveira}

Doutora em Ciências Sociais pela UFSCar (2006), com período sanduíche pela Northwestern University (2004-2005). Fez pós-doutorado em Ciência Política, pela USP (2009-2010), e especialização em Metodologia de Pesquisa, pela University of Michigan (2008). Diretora de Projetos do Departamento de Pesquisas judiciárias do Conselho Nacional de Justiça

\section{Pâmela Tieme Barbosa Aoyama}

Graduada em Biblioteconomia pela Universidade de Brasília(2011). Tem experiência na área de Ciência da Informação. Bibliotecária do Conselho Nacional de Justiça 